Innlegg på inntil 400 ord lastes opp i http://mc.manuscriptcentral.com/tidsskriftet.

Redaksjonen forbeholder seg retten til å foreta redaksjonelle endringer.

Forfattere av vitenskapelige artikler har automatisk tilsvarsrett (jf. Vancouver-gruppens regler).

\section{Nevropsykologisk utredning ofte nødvendig}

Anne-Kristine Schanke \& Hilde Bergersen kommenterer i Tidsskriftet nr. 1/2010 (1) vårt innlegg om skåringsverktøy i geriatri og rehabilitering (2). Vi takker for kommentaren, som gir oss mulighet til å presisere et poeng som nok ikke kom helt tydelig frem i vårt korte innlegg.

Hensikten med innspillet vårt var å henlede oppmerksomheten på tre skåringsverktøy som vi tror kan være nyttige, og å oppfordre til bruk av ensartede og sist validerte norske versjoner der flere er i omløp. Dette siste momentet er særlig relevant for Mini Mental Status Evaluering (MMSE) og Barthel ADL-indeks.

Når det gjelder Screeninginstrument for nevropsykologiske symptomer ved slag (SINS), var det på ingen måte vår hensikt å lansere dette som et alternativ til nevropsykologisk utredning. Dette lille instrumentet er, som navnet antyder, nettopp ment for screeningformål. Den undersøkelsen som er utført sammen med Schanke og Bergersen (3), synes vi indikerer at for nettopp et slikt formål kan instrumentet ha sin berettigelse, og kanskje gi minst like mye informasjon som noe større screeningtester (f.eks. Cognistat). Nettopp fordi SINS er lite og raskt i bruk, håper vi det kan senke terskelen for å tenke på muligheten av kognitive funksjonsforstyrrelser, og dermed bidra til at flere pasienter blir henvist til nevropsykologisk utredning. Vi er helt enig med Schanke \& Bergersen $i$ at langt grundigere undersøkelser enn SINS må gjøres der det er behov for det, og at det ofte vil være tilfellet.

\section{Jorunn L. Helbostad}

Ingvild Saltvedt

Norges teknisk-naturvitenskapelige universitet

\section{Carsten Strobel}

Lovisenberg Diakonale Sykehus

\section{Unni Sveen}

Kjersti Nøkleby

Torgeir Bruun Wyller

Oslo universitetssykehus, Ullevål

\section{Litteratur}

1. Schanke A-K, Bergersen H. Nevropsykologiske tester ved slag. Tidsskr Nor Legeforen 2010; 130: 13

2. Helbostad JL, Saltvedt I, Strobel C et al. Skåringsverktøy i geriatri og rehabilitering. Tidsskr Nor Legeforen 2009; 129: 2020

3. Nøkleby K, Boland E, Bergersen $\mathrm{H}$ et al. Screening for cognitive deficits after stroke: a comparison of three screening tools. Clin Rehabil 2008; 22: 1095-104.

\section{En rose er en rose er en rose}

Avgjørelsen om å erstatte navn som Aker sykehus med «sykehusområdet på Sinsen» og liknende, som ble kommentert på lederplass i Tidsskriftet nr. 2/2010 (1), minner meg om språkbruken i gamle DDR, hvor hva vi kjenner som «ku» ble omtalt som «melkproduserende storfe-enhet».

\section{Arne Reimers}

St. Olavs hospital

\section{Litteratur}

1. Haug C. Fratatt identiteten. Tidsskr Nor Legeforen $2010 ; 130: 131$

\section{RETTELSE}

Levertransplantasjon i Norge gjennom 25 år

Tim Scholz, Tom H. Karlsen, Truls Sanengen, Erik Schrumpf, Aksel Foss, Pål Dag Line, Kirsten Muri Boberg, Pål Foyn Jørgensen, Bjarte Fosby, Øystein Bentdal, Anniken Bjørnstad Østensen, Svein Osnes, Fridtjov Riddervold, Håkon Haugaa, Jon Hausken, Jon Bragi Bergmann, Stein Foss, Kristian Bjøro

Tidsskr Nor Legeforen 2009; 129: 2587-92

I denne artikkelen er det blitt en feil i forfatterrekkefølgen (s. 2587 og 2591) grunnet uvanlig oppsett. Riktig skal være: Tim Scholz, Tom H. Karlsen, Truls Sanengen, Erik Schrumpf, Pål Dag Line, Kirsten Muri Boberg, Pål Foyn Jørgensen, Bjarte Fosby, Øystein Bentdal, Anniken Bjørnstad Østensen, Svein Osnes, Fridtjov Riddervold, Håkon Haugaa, Jon Hausken, Jon Bragi Bergmann, Stein Foss, Kristian Bjøro, Aksel Foss 